\title{
The Construction of Local Cultural Publicity Translation System
}

\author{
Siyu Zou \\ Nanchang Institute of Technology
}

\author{
Keywords: Publicity Translation; English Translation; Translation Theory
}

\begin{abstract}
Publicity translation is a kind of transformation and communication of external discourse, which aims to promote the understanding of Chinese history, culture, politics, economy, society, value system and internal and external policies. In the background of the transformation of the international image of China, as the information of public diplomacy activities, foreign publicity translation plays a to foreign audiences speak good Chinese story, the spread of good Chinese sounds good interpretation with the contemporary mission of Chinese characteristics. Public diplomacy is the latest development of foreign propaganda, so it should be associated with the concept of communication to carry out public diplomacy and foreign publicity translation. With local cultural outreach to Chinese English translation this dissertation as the research object, discusses the guiding role of functional equivalence theory and Skopos Theory of local culture of foreign publicity translation.
\end{abstract}

\section{Introduction}

Publicity translation is one of the most important skills of foreign journalists in the process. It is very important. Similarly, Chinese news if the translation is ready to be accepted by Western readers, but also to promote the national culture and national conditions of our country and enhance the role of the national image.

Global economic development is increasingly close, Chinese local culture will further participation in international division of labor, in this process, the local culture of foreign publicity material translation. Translation of foreign publicity materials for local culture aims to introduce enterprises to foreign potential partners, and to promote trade and cooperation. China's foreign economic exchanges, local culture and foreign publicity translation have a typical and reference value. This paper for the local culture some publicity materials were researched and analysis, found that some translations in accordance with western language and culture habits, and ultimately contributed to the economic cooperation. But there is many "hard translation" of the injury, the specific performance: in terms of word translation word for word translation, syntactic aspects to apply Chinese syntax, the contents of the information level of all translation. In fact, bilingual expression in habits and ways of thinking and values were obviously different, if you copy the literal translation of words and structure, on the surface of faithful of the original, but the translation often makes readers confusing, the expected effect is actually not very well made in translation. This kind of "hard translation" injury actually limits the insular culture and even the whole country. In this paper, through the theoretical study of overseas publicity translation, this paper puts forward the principles and methods of the translation practice.

\section{Direction of Translation}

Context and Translation. Language and context influence each other, thus forming a certain degree of pragmatic meaning, in addition to the meaning of language cognition, the pragmatic meaning should be affirmed in the context. Context, which covers many factors that affect the pragmatic context, although it is restricted to the language of the pragmatic environment, but it can provide the conditions for the production of pragmatic meaning. Usually, the context covers the accurate location, communication environment, and the topic of participants, which directly influence the participants understand and use specific language abilities and skills. 
Cultural Context and Translation. In the process of translation, should attach great importance to the cultural context. This is because the different cultural background may make the use and expression of language and collocation is very different. Ideas and products from the perspective of the translator, its service object is not too understand or don't understand the society and the culture of the source language to the target language readers, the translator in the translation process has the responsibility to also have an obligation to the formation of the source language culture environment as the background, pragmatic habits and use of the target language readers with translation expression to the target readers and make the target language reader does not exist in comprehension difficulties.

Relevance and Translation. According to the relevant theory of pragmatics, it is a pity that no matter whom the translator is dealing with the translation, as long as it is able to accurately express the meaning of the original text and achieve the goal of linguistic communication. In this way, we can take advantage of the correct theory to guide the translation skills, so as to better express the exact meaning of the original text.

\section{Concept of Publicity}

Publicity translation is a kind of transformation and communication of external discourse, which is intended to promote the understanding of Chinese history, culture, politics, economy, society, value system and internal and external policies. External propaganda mainly has the following three concepts:

Propaganda Idea. Publicizing refers to the activities of some kind of doctrine, idea, thought or point of view, in order to achieve the purpose of definite objects. In Chinese culture, Propaganda is the dissemination of ideas of neutral words, not derogatory. Especially in the external communication activities, this feature is more prominent.

Explanation Idea. Explanation refers to exchange and exchange information with others. Compared with the publicity, the emphasis on domestic and foreign interaction and two-way financing, highlighting the audience's awareness of the spread of exotic. As Zhao Qizheng said, if you always want to show the real China to the world, you cannot ignore the importance of the audience. The idea is good to the domain of domestic information.

Persuasion Idea. Persuasion talks about the transfer of the interactive information between the participants, and to promote the individual or group to voluntarily change their views or behaviors. With respect to that persuasion is not only the awareness of the audience again for the response, but also pay close attention to the awareness of rhetoric, pay close attention to how to effectively use language and other symbolic resources to influence foreign audiences thought, feelings, attitude and behavior.

\section{Build a Complete Translation System, Promote the Construction of Local Culture}

Complete publicity translation system includes in the correct translation principles as under the guidance, to enhance the image of the indigenous culture as the goal, to the cultivation of professional foreign publicity translation talents to protect, to government monitoring and support as a fundamental.

Adhere to the Correct Principles of Translation as a Guide. Publicity translation in addition to follow the translation work should follow the "faithfulness, expressiveness and elegance" standard, but also to follow the features of "three close to" principle, which is close to the actual development of China, close to the foreign audience demand for Chinese information, close to the foreign audience's habit of thinking.

To Promote the Image of City Culture as the Goal. The purpose of foreign publicity translation is to let the world understand China, understand the local culture and development of the city, so that the local city in the world, to get better development. A large number of foreign publicity translation practice has proved that if the proper translation strategies, accurate information source translation into the target language, you can get the correct understanding and 
the approval of the audience, which received the good dissemination effect, to achieve the purpose of enhancing the image of the city.

Training Professional Translation Talents. As a kind of translation, publicity translation has a very big difference with common translation, so it needs to have professional quality and level.

\section{Conclusion}

The basic ideas of publicity translation, explanation and persuasion covering publicity. Publicity highlights the point of view, the emphasis on information exchange, to persuade the audience to accept. In practice, there is not any single concept can fully play the actual mission and historical responsibility of external publicity translation. There is closely relation between the city image and foreign publicity translation, construct the complete system of local culture of foreign publicity translation, can better zone dynamic foreign publicity translation research and practice work carried out, so as to improve the actual effect of the external propaganda work, set a good image of the city for the local city, seize the opportunity to promote economic and social development to create a play a role in actively promoting the international public opinion in a positive and harmonious and stable political environment.

\section{Acknowledgements}

Project funding: Social science planning project of Jiangxi Province in 2013 (Research on cultural default and its compensation based on interpretive translation theory, Id: 13YY22)

\section{References}

[1] Liu D. Strategies in C-E Translation of Public Sign-Based on the Study of Public Sign Translation of Qingdao[J]. Theory \& Practice in Language Studies, 2013, 3(6).

[2] Khan M K R, Malik A. A Study of Translation Definition and Inverse Textual C-E Translation Strategy in Perspective of Cognitive Linguistics[J]. Journal of Hebei Polytechnic University, 2011, 428(1):64-69.

[3] Wang, Xiaonong. On Teaching C-E Translation to Chinese Advanced EFL Learners. Emerging Computation and Information teChnologies for Education. Springer Berlin Heidelberg, 2012:221-228.

[4] Lin S, College W. A study on international publicity translation strategies from the perspective of skopos theory[J]. Journal of Jiamusi Education Institute, 2014, 19(7) :893-907.

[5] Huang Y. Homogenization as the Major Strategy in Chinese-English Publicity Translation[J]. Journal of Hunan University of Technology, 2014.

[6] Sun J, Cui J. On cultural strategies in publicity translation of Chinese universities from the perspective of Skopostheorie[J]. Journal of Henan University of Urban Construction, 2014.

[7] Li Y. On Cultural Differences in the International Publicity Translation[J]. Journal of Jilin Institute of Chemical Technology, 2014.

[8] Guo X. Foreign Publicity Translation's Impact upon Cultural Dissemination[J]. Academic Exchange, 2013.

[9] Chen S Y. International Publicity Translation: Wrestling of Ideologies[J]. Journal of Changsha University of Science \& Technology, 2013.

[10]Ling L I. On Addition and Deletion of International Publicity Translation[J]. Journal of Linyi University, 2013. 
[11]Zhao J Q, Shuai W U, Long M H. Application of Parallel to Corporate Publicity Translation[J]. Overseas English, 2013.

[12] Sun F. Translators' Subjectivity in External Publicity Translation[J]. Canadian Social Science, 2013, 9(6) :227-230. 